\title{
The Nile Basin
}





\title{
The Nile Basin
}

\author{
National Determinants \\ of Collective Action
}

John Waterbury

Yale University Press

New Haven and London 
Copyright (C) 2002 by Yale University.

All rights reserved.

This book may not be reproduced, in whole or in part, including illustrations, in any form (beyond that copying permitted by Sections I07 and Io8 of the U.S. Copyright Law and except by reviewers for the public press), without written permission from the publishers.

Set in Adobe Garamond type by The Composing Room of Michigan, Inc.

Printed in the United States of America by Sheridan Books, Ann Arbor, Michigan.

Library of Congress Cataloging-in-Publication Data

Waterbury, John.

The Nile Basin : national determinants of collective action / John Waterbury.

p. $\mathrm{cm}$.

Includes bibliographical references and index.

ISBN 0-300-08853-I (cloth : alk. paper)

I. Water-supply-Nile River Watershed-Management_International cooperation. 2. Water resources development-Nile River WatershedInternational cooperation. 3. Water resources development-Government policy_Nile River Watershed. I. Title.

TD319.N6 W38 200I

$333.9 I^{\prime} I^{\prime} 0962-\mathrm{dc} 2 \mathrm{I}$

2001045488

A catalogue record for this book is available from the British Library.

The paper in this book meets the guidelines for permanence and durability of the Committee on Production Guidelines for Book Longevity of the Council on Library Resources.

IO $9 \begin{array}{lllllllll}9 & 8 & 7 & 6 & 5 & 4 & 3 & 2 & \text { I }\end{array}$ 